\title{
THE INFLUENCE OF PUBLIC RELATIONS CAMPAIGN \#NOSTRAWMOVEMENT ON FAST FOOD RESTOURANT CONSUMER PARTICIPATION
}

\author{
Oleh: \\ Marcella Novena ${ }^{1)}$ \\ Siti Meisyaroh ${ }^{2}$
}

\begin{abstract}
News about environmental issues have led many companies and fast food restaurants like KFC started the Public Relations campaign movement with the theme \#NOSTRAWMOVEMENT which was done simultaneously in all of their outlets in Indonesia. KFC Raden Inten becomes case in study. This study aims to determine the influence of the Public Relations campaign \#NOSTRAWMOVEMENT will influence consumer participation in KFC Raden Inten. This research uses stimulus- respons $(S-R)$ theory and participation concept which can be interpreted as taking part or taking a role in activities or activities. The author uses this theory because I want to know how much consumer participation is influenced by Public Relations campaign \#NOSTRAWMOVEMENT of KFC. Participation is divided into two categories, direct participation and indirect participation. In this study, researchers used quantitative research with a descriptive and explanatory approach. Data collection techniques used in this study were documentation and questionnaire filling as part of the survey. Researchers used a survei method using a questionnaire. Data analysis techniques using validity test, reliability test, normality test, $t$ test, $F$ test and $R^{2}$ test. Based on the data processing carried out, this study obtained the result that the relationship between the Public Relations campaign variables and consumer participation had a positive and significant influence.
\end{abstract}

Keywords: Public Relations Campaign, Consumer Participation, Consumer Attitude

\begin{abstract}
ABSTRAK
Banyaknya pemberitaan mengenai isu lingkungan membuat salah satu restoran cepat saji (KFC) memulai gerakankampanye Public Relations dengan tema \#NOSTRAWMOVEMENT yang di lakukan secara serentak di semua gerai di Indonesia, tidak terkecuali KFC Raden Inten. Penelitian ini bertujuan untuk mengetahui pengaruhkampanye Public Relations \#NOSTRAWMOVEMENT terhadap partisipasi konsumen KFC Raden Inten. Penelitian ini menggunakan teori stimulus respons (S-R) dan juga konsep partisipasi. Peneliti menggunakan teori ini karena ingin mengetahui partisipasi konsumen dipengaruhi oleh kampanye Public Relations \#NOSTRAWMOVEMENT dari KFC. Partisipasi di bagi menjadi dua, partisipasi langsung dan partisipasi tidak langsung. Dalam Penelitian ini, Peneliti menggunakan dengan riset kuantitatif dengan pendekatan deskriptif dan eksplanatori. Teknik pengumpulan data yang digunakan dalam Penelitian ini adalah dokumentasi dan pengisian angket kuisioner sebagai bagian dari pada survei. Peneliti menggunakan metode survei dengan menggunakan kuisioner. Teknik Analisa data menggunakan uji validitas, uji realibilitas, uji normalitas, uji t, uji $\mathrm{F}$ dan Uji $\mathrm{R}^{2}$. Berdasarkan pengolahan data yang dilakukan, kesimpulan dari penelitian ini memperoleh hasil bahwa hubungan diantara variabel kampanye Public Relations dan partisipasi konsumen terdapat pengaruh yang signifikan dan positif.
\end{abstract}

\section{Kata Kunci: Kampanye Public Relation, Partisipasi konsumen, Sikap Konsumen}

Program Studi Ilmu Komunikasi Institut Bisnis dan Informatika Kwik Kian Gie. Jl. Yos Sudarso No. Kav 87, Kota Jakarta Utara, Daerah Khusus Ibukota Jakarta 14350. Telp. (021) 65307062. Email: marcellaadria16@ gmail.com

Program Studi Ilmu Komunikasi - Institut Bisnis dan Informatika Kwik Kian Gie 


\section{INTRODUCTION}

Coverage on environmental issues, health issues, and social issues dealing with global in the media. This has led many companies and fast food restaurants to carry out social movements, known as Public Relations campaigns. According to Moriarty., Et al (2011: 625), Public Relations campaigns are used to influence or change public opinion and campaigns are usually conducted to deal with marketing from other parties. One of them is a fast food restaurant (KFC) which started with the theme \#NOSTRAWMOVEMENT which was introduced to franchise networks throughout Indonesia, including KFC Raden Inten. According to Gani (2014, accessed on 30 October 2019), conceptually, a campaign is defined as a planned, gradual and sometimes culminating activity of delivering information, which aims to influence a person's attitudes, opinions and opinions.

Disposing of garbage into the ocean can certainly damage the ecosystem and also kill living things that are there. Various types of waste such as HDPE plastics, glass, textile fabrics, plastic packaging, pet plastics, styrofoam, clear plastics, plastic straws, plastic bags, cans and so on. According to Bila, it can reach 31.3 kilograms $/ 100 \mathrm{~m} 2$ of waste that is only under the sea, while the total can reach 81.2 kilograms of marine and coastal waste. Where weighing 1.45 kilograms is plastic straw waste. The \#NOSTRAWMOVEMENT Public Relations Campaign which has only been held in the past two years has been able to help reduce plastic waste. To get more impact, the DCA team invited one of the big restaurants like KFC. KFC has outlets in 34 provinces in Indonesia and is also a major contributor to plastic straw waste.

Initially carried out at $6 \mathrm{KFC}$ outlets in Jabodetabek where, at first this movement started by not providing a straw dispenser and only in give when consumers ask. However, over time this movement became a National movement in $714 \mathrm{KFC}$ outlets throughout Indonesia by not providing straws directly and not using straw dispensers, unless they really needed it for people with disabilities, as well as encouraging consumers to get used to not using straws.

The use of social media like Instagram is also very effective in helping disseminate the Public Relations campaign that is being run. This Public Relations campaign was also spread by KFC through accounts Instagramnya at $@$ kfcindonesia. By providing facts and negative impacts about plastic waste, KFC also encourages people to want to use stainless straw instead. There are also other activities carried out with DCA such as talk shows and fashion shows, KFC good journey.

Community participation is very important in the success of an action or event. Without the participation of the target or the community concerned, an objective cannot be achieved. According to Karianga (in Lilies, 2014: 8), etymologically, participation comes from the Latin pars which means part of cpere, which means taking, so it means "taking part". In English, participation or participation means taking part or taking part.

Like the \#NOSTRAWMOVEMENT campaign. The objectives of this campaign could not have been achieved without the participation of the community. Therefore, the purpose of this campaign is to be able to foster a desire to participate from the community, especially KFC consumers, who are expected to get results that people can use less and wiser to use plastic straws. With the description above, the researcher wants to know about the effect of the \#NOSTRAWMOVEMENT Public Relations campaign on KFC Raden Inten consumer participation.

\section{LITERATURE REVIEW}

Stimulus Response Theory (S-R) is the most basic model of communication. This theory is influenced by the psychological discipline that links Stimulus-Response. This theory assumes communication as a very simple action-reaction process, where verbal words, non-verbal cues, 
pictures, and certain actions can stimulate others to respond in certain ways (Mulyana, 2008: 143).

This theory also assumes a message that has been prepared and distributed systematically and on a very broad scale, so that the message is simultaneously conveyed to a number of individuals, and not shown to individuals. Stimulus - Response. In the early days of the emergence of mass communication models, it was always described as one-way only. This is because at that time the audience was still considered too passive and accepted all the messages conveyed. In mass communication, the stimulus response model involves two components, namely the mass media and audiences.

According to Karianga (in Lilies, 2014: 8), etymologically, participation comes from the Latin pars which means part of cpere, which means taking, so it means "taking part". In English, participation or participation means taking part or taking part. So it can be concluded that participation is taking a role in activities or activities. The concept of participation can also be interpreted as a relationship between society and the power system in the development process which is equally correlated.

According to Sundaningrum (in Bahaddur, 2012: 13), participation can be divided into two based on the way of involvement, namely, direct participation, participation that occurs when individuals perform certain activities in the participation process. This participation occurs when everyone can raise views, discuss the subject matter, raise objections against the wishes of others or against their words and indirect participation, participation that occurs when individuals delegate their right to participate.

According to Gani (2014, accessed on 30 October 2019), Public Relations campaigns today have become very important, the campaign itself means a planned communication to achieve certain goals and seeks to influence audiences. According to Rahmadilaga (2017: 9), the PR (Public Relations campaign) campaign in communication aims to create understanding, knowledge, interest, understanding, support and awareness from various parties to obtain an image for the institution or organization it represents.

According to Gregory (2018: 78), there are three levels in the objectives of the Public Relations campaign, namely, first awareness (cognitive), which is the stage where the target public thinks about something and tries to introduce a certain level of understanding. Second, attitudes and opinions (affective), namely the stage of making the target public to make a certain attitude or opinion about a subject. So that the public can trust, be interested and like the message conveyed.

The affective component affects emotions or feelings for a particular product or brand and determines whether or not consumers like certain products. Third, behavior (conative), which is the stage of making the target public act as desired. The conative component affects a person in taking action and behavior in a certain way towards an object of attitude and determines whether consumers will buy or reject a product.

The object of this research is consumers from KFC Raden Inten who are aware of the \#NOSTRAWMOVEMENT Public Relations campaign and participate in campaign activities that take place in the KFC area.

\section{RESEARCH METHODS}

Researchers used a survey by collecting data through filling out a questionnaire as part of this research and also using quantitative descriptive and explanatory research. According to Kriyantono (2014: 55), descriptive quantitative research is used for describing the population being studied, this research focuses on current behavior and consists of one variable. While explanatory aims to obtain information, information, data regarding things that are not yet known.

Exploratory research is carried out if the researcher has not obtained preliminary data so that he does not have a picture at all about the things to be studied. This research was conducted by connecting or looking for cause and effect 
between two or more concepts (variables) to be studied. Variables are concepts that can be measured. (Kriyantono, 2014: 59).

variable is a concept in concrete form or operational concept. According to Kriyantono (2014: 20), a variable is a low-level concept, whose references are relatively easy to identify and observe and easy to classify, sort or measure. This research is a bivariate analysis. According to Kriyantono (2014: 22), bivariate analysis is an analysis carried out to test the relationship of one independent variable to the dependent variable. In this study, the independent variable $(\mathrm{X})$ is the \#NOSTRAWMOVEMENT Public Relations campaign and the dependent variable $(Y)$ is consumer participation.

Data collection techniques used in this study were documentation and filling out a questionnaire as part of the survey. The questionnaire is a closed statement, can be given in person or sent via the internet. Based on the source, data collection techniques in a study can be grouped into two types of data, namely primary data collection in the form of questionnaires and documentation. Secondary data are books and websites.

In this study, researchers used the NonProbability Sampling technique with accidental sampling. The sample was determined as many as 60 respondents because the researcher did not know with certainty the number of consumers at KFC Raden Inten every day, considering that the number of consumers who came was not always the same every day. This is the researcher's decision to determine the sample without using the Slovin or Yamane formula.

In this study, the researcher has distributed questionnaires to 60 respondents directly in accordance with the criteria set by the researcher, there are two criteria, namely based on age with a range from 15 - 58 years of age and based on gender with a total of 27 female respondents and men as many as 34 people.

Based on data distributed to 60 respondents, where the first 30 respondents were conducted from 15-16 January 2020 and the remaining 30 respondents were conducted on 18-20 January
2020. The researcher then tested the validity of 38 statements and got valid results with $r_{\text {table }}>r_{\text {hitung }}$ for all existing statements.

The reliability test that the researchers conducted used the SPSS statistical application with the calculation of Cronbach's Alpha $\geq 0.7$. Therefore, the results of the calculation of variables in this study were declared reliable because the results of Cronbach's Alpha were $0.978 \geq 0.7$.

The average value that is owned by the \#NOSTRAWMOVEMENT Public Relations campaign variable has very good results with an average score of 4.3 and the average value possessed by the consumer participation variable has very good results with a score of 4.2.

From the results of the questionnaire tested through SPSS Statistic 22 for both variables normally distributed with Asymp. Sig for Public Relations campaign variable $0.077 \geq 0.05$ and for Asymp. The sig of the consumer participation variable is $0.187 \geq 0.05$, it can be concluded that this study has met the normality requirements.

Based on the statistical test, it was found that the relationship between the two variables showed the number 0.918 which showed that the relationship between the two variables was very high or strong.

Based on the results of calculations with SPSS statistics 22, it shows that the two variables have a linear relationship, this is shown in the Sig.

Deviation from Linearity $0.280 \geq 0.1$, which means that the two variables are stated to have a linear relationship with the provisions of the significance value limit of $10 \%$ or 0.1 .

In the calculation of the table is 1.67155 and $r_{\text {count }}$ for X1 (cognitive) was 3,761, X2 (affective) was 2,439 and $\mathrm{X} 3$ (conative) was 2,218 . Then, value $t_{\text {count }}$ for the three variables greater than $\mathrm{t}_{\text {table. }}$ When viewed from the Sig. For the three variables, $\mathrm{X} 1$ is $0.000<0.05, \mathrm{X} 2$ is 0.002 $<0.05$ and $\mathrm{X} 3$ is $0.008<0.05$. So that the prevailing hypothesis is Ha: $\beta>0$; means that there is a significant and positive influence between the independent variables, namely the \#NOSTRAWMOVEMENT Public Relations 
campaign on the dependent variable, namely consumer participation in KFC Raden Inten.

Based on the calculations obtained, the $F_{\text {count }}$ is 92,952 and sig 0,000 . For the $F_{\text {table }}$ value that the researcher got was 4.007. This shows that $F_{\text {count }}>F_{\text {table, namely }} 92.952>4.007$. For the sig value, it must be $<0.05$ to be significant, it can be seen from the table above that the sig value is $0.000<0.05$ which explains that the model in this study is suitable for use. This identifies that the \#NOSTRAWMOVEMENT Public Relations campaign against consumer participation in KFC Raden Inten with the regression model that the researchers created proved significant.

Based on the calculation results, the value of $\mathrm{R}^{2}$ shows the number 0.616 , which means that $61.6 \%$ of the \#NOSTRAWMOVEMENT Public Relations campaign variable contributes quite a lot to consumer participation in KFC Raden Inten. This shows that the effect of the \#NOSTRAWMOVEMENT Public Relations campaign is quite influential on consumer participation in KFC Raden Inten and the remaining $38.4 \%$ is influenced by other factors.

\section{RESEARCH RESULTS AND DISCUSSION}

Based on the results of the research that has been obtained, it proves that there is an effect of the \#NOSTRAWMOVEMENT Public Relations campaign on KFC Raden Inten consumer participation. Based on the results for validity testing using 60 respondents, it was stated that 38 statements were declared valid with the calculation of $r$ count $>r$ table. For reliability calculations, Cronbach's Alpha results are also obtained from $0.981 \geq 0.7$, which means that the list of statements has met the reliable requirements.

Based on the results of the F test, it shows that the use of the model in this study is considered appropriate and appropriate, seen from the calculated $F$ value> F table, namely 92,952> 4,007. Based on the statistical test, it was found that the relationship between the two variables showed the number 0.918 which showed that the relationship between the two variables was very high or strong. When viewed from the correlation between the two variables, it shows the number 0.918 which shows the relationship between the two variables is very high or strong.

According to Rahmadilaga (2017: 9), the PR (Public Relations campaign) campaign in communication aims to create understanding, knowledge, interest, understanding, support and awareness from various parties to obtain an image for the institution or organization it represents. This was also carried out by KFC, which carried out the \#NOSTRAWMOVEMENT campaign which aims to provide understanding and knowledge to consumers about reducing the use of straws in the KFC Raden Inten outlet environment.

Likewise, KFC Raden Inten provides support and awareness for consumers to care about the environment by being interested in not using plastic straws in KFC Raden Inten outlets. The results of distributing questionnaires to 60 respondents who are KFC Raden Inten consumers, from the $t$ test it can be concluded that the effect of the independent variable, namely the \#NOSTRAWMOVEMENT Public Relations campaign, on the dependent variable, namely the participation of KFC Raden Inten consumers, has a significant and positive effect.

The results of the calculation of the $t$ test for X1 (cognitive) amounted to 3,761 1.67155, X2 (affective) amounted to 2.439>1.67155 and X3 (conative) was 2.218> 1.67155. When viewed from the Sig. For the three variables, X1 is 0.000 $<0.05, \mathrm{X} 2$ is $0.002<0.05$ and $\mathrm{X} 3$ is $0.008<0.05$. Therefore, it can be concluded that Ho is rejected and $\mathrm{Ha}$ is accepted, $\mathrm{Ha}$ is accepted because tcount> ttable and also the Sig. less than 0.05 .

Judging from the average value in the descriptive statistical test, the value on the \#NOSTRAWMOVEMENT Public Relations campaign variable has excellent results with a score of 4.3 , where the respondents agree that the delivery of the \#NOSTRAWMOVEMENT 
Public Relations campaign can influence them to participate. When viewed from each dimension of the existing Public relations campaign, starting from the dimension of awareness (cognitive) the highest value lies in statement number 6 , which means that respondents are aware and understand what they want to convey in the \#NOSTRAWMOVEMENT Public Relations campaign program before they want to participate with value mean 4.38 .

Whereas in the dimension of attitudes and opinions (affective) the highest mean value lies in statement number 16 , where respondents like the messages conveyed in the \#NOSTRAWMOVEMENT Public Relations campaign with a mean value of 4.48 . In the behavioral (conative) dimension, the highest mean value lies in statement no.22, that is, the respondents will reduce the use of straws after knowing the \#NOSTRAWMOVEMENT Public Relations campaign, the mean value in this statement is 4.5 .

According to Ach. Wazir Ws., Et al. (in Ripai, 2013: 20), participation can be defined as a person's conscious involvement in social interactions in certain situations. With that understanding, a person can participate when he finds himself with or in a group, through various processes of sharing with others in terms of values, traditions, feelings, loyalty, obedience and shared responsibility.

Judging from the average value in the descriptive statistical test of the value on the consumer participation variable, the average value of the consumer participation variable has very good results with a score of 4.2 , meaning that consumers agree to participate after seeing the Public Relations campaign \# NOSTRAWMOVEMENT. When viewed from the dimension of direct participation, the highest value lies in statement number 1 , which means that respondents are interested in participating directly not to use plastic straws with a mean value of 4.5. Whereas in the indirect participation dimension the highest mean value lies in statement number 16, where respondents agree with the \#NOSTRAWMOVEMENT Public Relations campaign indirectly making the environment cleaner than straw waste with a mean value of 4.45 .

Based on the correlation value between the \#NOSTRAWMOVEMENT Public Relations campaign on consumer participation, KFC Raden Inten received a value of $61.6 \%$, which means that the \#NOSTRAWMOVEMENT Public Relations campaign variable contributed quite high to consumer participation in KFC Raden Inten. This shows the effect of the \#NOSTRAWMOVEMENT Public Relations campaign is quite influential on consumer participation in KFC Raden Inten and the remaining $38.4 \%$ is influenced by other factors.

The desire to participate either directly or indirectly, in not using plastic straws among KFC Raden Inten consumers can arise and be influenced after seeing the \#NOSTRAWMOVEMENT Public Relations campaign held by KFC, so in conclusion, the \#NOSTRAWMOVEMENT Public Relations campaign has an effect on consumer participation in KFC Raden Inten.

\section{CONCLUSION}

Based on the analysis of the results of the research conducted, the researcher concluded that there was a fairly high influence compared to other factors. This shows that KFC Raden Inten consumers want to participate in not using a straw when they find out about this campaign. Based on the correlation test between the two variables which shows the relationship between the two variables is very high or strong. In the sense that the \#NOSTRAWMOVEMENT Public Relations campaign is very influential in encouraging consumers to participate.

The following are the results of hypothesis testing. First, cognitive aspects have a positive and significant effect on consumer participation. 
Second, the affective aspect has a positive and significant effect on consumer participation and also, the three conative aspects have a positive and significant effect on consumer participation. The campaign has been spread evenly throughout KFC outlets in Indonesia, so consumers can easily find out about the campaign, especially the campaign being carried out is supported by not providing a straw from KFC. When viewed from the results of data testing that researchers have conducted, the \#NOSTRAWMOVEMENT Public Relations campaign has an effect on consumer participation in KFC Raden Inten.

Researchers suggest that further researchers be able to measure the effect of the \#NOSTRAWMOVEMENT Public Relations campaign on consumer participation so that it is even better and examined in depth in order to explore and develop new concepts regarding Public Relations campaigns and consumer participation that have not been done in this study.

Suggestions for further researchers are also to be able to measure the influence of Public Relations campaigns on other campaigns such as \#budayabeberes and others regarding environmental issues that are being carried out a lot. These suggestions are reviewed from the number of hashtags used in fast food restaurants other than KFC. Future researchers can also change the object of research because many topics are starting to be similar to \#NOSTRAWMOVEMENT.

After going through a series of processes, through this research the researcher wants to remind the next researcher, if you want to do research in a large and well-known restaurant, firstly, the respondent's data collection is done directly, you must first research the company that you want to be the object of research.

For KFC companies, it is hoped that this research can be used as an evaluation material regarding the Public Relations campaign that has been carried out for almost the last three years, because when viewed from the calculation of the effect of this Public Relations campaign the effect on consumer participation is quite high. Placement of pictures or videos about this campaign can also be reproduced so that people will be more aware of the existence of this campaign.

Researchers hope that this research can be thought material for students both at the Kwik Kian Gie Institute of Business and Informatics and other campuses as learning materials about Public Relations campaigns.

The researcher also hopes that in the future this research can be made with different methods, for example with qualitative methods or other things by examining Public Relations campaigns carried out by other companies and also examining from the social media side. The theory used can also be taken from others.

The researcher also found that there were weaknesses in this study, namely the researcher used non-probability techniques to take samples, where the researcher should use probability techniques, so the researcher expected the next researcher to use the correct technique. The number of samples used is also expected to be more than just 60 respondents.

\section{REFERENCES}

\section{Books}

Cangara, H. Hafied (2010), Pengantar Ilmu Komunikasi, Jakarta: RajaGrafindo Persada.

Effendy, Onong Uchjana. (2003). Ilmu, teori dan filsafat komunikasi. Bandung: PT. Citra Aditya Bakti.

Gregory, Anne (2018), Perencanaan dan Manajemen Kampanye Public Relations, Jakarta: Penerbit Erlangga.

Kotler, Philip dan Keller, Kevin Lane (2016), Marketing Management Global Edition, Amerika: Pearson.

Kriyantono, Rachmat (2014), Teknik Praktis Riset Komunikasi: Disertai Contoh Praktis, Riset Media, Public Relation, Advertising, 
Komunikasi Organisasi, Komunikasi Pemasaran, Jakarta: Kencana.

McQuail, D (2011), Teori Komunikasi Massa McQuail. Jakarta: Salemba Humanika.

Moriarty, Sandra., et al (2011), Advertising, Edisi Kedelapan, Jakarta: Kencana.

Morissan, Alastair M. (2010), Periklanan Komunikasi Pemasaran Terpadu, Jakarta: Penerbit Kencana.

-------, (2013), Teori Komunikasi: Individu Hingga Massa, Jakarta: Kencana.

Mrbambang (2012), Instagram Handbook, Jakarta: Mediakita.

Mulyana, Deddy (2008), Ilmu Komunikasi: Suatu Pengantar, Bandung: Remaja Rosdakarya.

Priyatno, Duwi (2016), Belajar Alat Analisis Data dan Cara Pengolahannya Dengan SPSS. Yogyakarta: Penerbit Gava Media.

Prayitno, Sunarto dan Rudi Harjanto (2017), Manajemen Komunikasi Pemasaran Terpadu, Depok: Raja Grafindo.

Ruslim, Tommy Setiawan \& Richard Andrew (2012), Pengaruh Brand Image dan Product Knowledge terhadap Purchase Intention (Kasus: Kosmetik Merk X).

Seitel, Fraser P (2017), The Practice of Public Relationss Thirteen Edition, New York: Pearson.

Sugiyono (2017), Metode Penelitian Kuantitatif, Kualitatif dan Kombinasi (Mixed Methods), Bandung: Penerbit Alfabeta.

Venus. A. (2014), Manajemen Kampanye Panduan Teoritis dan Praktis Mengefektifkan Kampanye Komunikasi, Bandung: Simbiosa Rekatama Media.

Zarella, Dan (2011), Social Media Marketing Book, Jakarta: Serambi Ilmu Semesta.

\section{Journals}

Anggani, Calisca Hardiana (2014), Pengaruh Program Kampanye "Say No To Plastic Bag” Oleh The Body Shop Terhadap Pertisipasi Masyarakat, Universitas Prof. Dr. Moestopo.

Firdiyah, Ratih (2018), Kampanye Sosial Gerakan Menutup Aurat di Bekasi. Universitas Islam "45" Bekasi.
Lestari, Tirta (2015), Skripsi: Pengaruh Terpaan Iklan Televisi Elevenia Terhadap Minat Beli Mahasiswa (Studi Pada Mahasiswa Ilmu Komunikasi Universitas Sultan Ageng Tirtayasa Angkatan 2012). Jurusan Ilmu Komunikasi Fakultas Ilmu Sosial dan Ilmu Politik Universitas Sultan Ageng Tirtayasa. Normawati, Siti Maryam, dan Anjang Priliantini (2018), Pengaruh Kampanye "Let's Disconnected To Connected" Terhadap Sikap Antik Phubbing (SurveiPada Followers Official Accound Line Starbucks Indonesia, FISIP, UPN.

Rahmadilaga, Reddi (2017), Skripsi: Strategi Public Relationss Pemerintahan Kota Bandung Dalam Pembentukan Opini Publik Kebijakan Pelanggaran Penggunaan Styrofoam. Jurusan Sains Komunikasi dan Pengembangan Masyarakat, Institut Pertanian Bogor.

Syaifudin, M. Eko Nur (2017), Komunikasi Kelompok Dalam Kampanye Sosial Komunitas Ketimbang Ngemus Regional Gresik, Universitas Islam Negri Sunan Ampel Surabaya.

Wulandari, Sisca (2019), Pengaruh Kampanye Komunikasi Pada Gerakan Gerakan "Bogoh Ka Bogor" Terhadap Perubahan Sikap Masyarakat (Studi Kasus Kecamatan Bogor Tengah), Universitas Pakuan Bogor.

Thesis

Amalia, Nur Fithry (2012), Skripsi: Kampanye Public Relations Dalam Membentuk Sikap Khlayak (Studi Pada Kasus Stop The Trafficking Of Childern and Young People yang Diselenggarakan Oleh The Body Shop Indonesia), Universitas Indonesia.

Bahaddur, Muslikh (2012), Skripsi: Partisipasi Orang Tua Siswa Dalam Pembelajaran di SD Islam Terpadu Salman Al Farisi Yogyakarta. Universitas Negeri Yogyakarta.

Lilies, Ikke (2014), Skripsi: Pengaruh Partisipasi Organisasi Terhadap Communication Skills Mahasiswwa di Institut Bisnis Dan Informatika Kwik Kian Gie. IBII (Tidak Dipublikasikan) 
Rahayu, Martiana Dwi (2018), Skripsi: Partisipasi Masyarakat Dalam Pembangunan Infrastruktur Di Desa Sinarsari Kecamatan Kalirejp Kabupaten Lampung Tengah, Universitas Lampung.

Ripai, Andi (2013), Skripsi: Partisipasi Masyarakat Dalam Pembangunan di Kecamatan Bontomatene Kabupaten Kepulauan Selayar, Universitas Hasanuddin.

\section{Web Article}

Arifah, Iffah Nur 2018, Gerakan Anti Sedotan Plastik Yang Kian Gencar di Indonesia, $A B C \quad N e w s$, https://www.abc.net.au/indonesian/201809-19/gerakan-anti-sedotan-plastik-diindonesia/10280154, diakses pada 27 Oktober 2019.

DiversCleanAction [@diverscleanaction]. (15 Mei 2017). Infografis Hasil Bebersih Sampah Pesisir Pulau Pramuka [Foto Instagram]. Diakses melalui https://www.instagram.com/p/BUGUdgwF liR/?igshid=104oqho0h $2 \mathrm{cwj}, 23$ Oktober 2019.

Ginting, Radian Nugraha 2019, "No Straw Movement", Sebuah Solusi Mengatasi Darurat Limbah Plastik di Laut Indonesia, Kompasiana, diakses 12 November 2019, https://www.kompasiana.com/radiangintin g/5d941f210d8230108240cd32/no-strawmovement-sebuah-solusi-mengatasidarurat-limbah-plastik-di-lautindonesia?page $=$ all.

Gani, Prita Kemal 2014, Kampanye Sosial, LSPR.edu, diakses 30 Oktober 2019, http://www.lspr.edu/pritakemalgani/kampa nye-sosial-2/.

Winarso, Bambang 2015, Apa Itu Instagram, Fitur dan Cara Menggunakannya? Daily Social, https://dailysocial.id/post/apa-ituinstagram, diakses pada 14 November 2019,

Kegiatan Usaha Perusahaan, PT Fastfood Indonesia, diakses 16 November 2019, http://kfcindonesia.kfcku.com/kegiatanusaha-perusahaan 